\title{
Siemenperunan tuoteseloste, jäljitettävyys varmistaa laadun
}

Timo Remes, Elina Virtanen

MTT Biotekniikka- ja Elintarviketutkimus, Tutkimusasemantie 15, 92400 Ruukki, etunimi.sukunimi@mtt.fi

\section{Tiivistelmä}

Elintarviketeollisuus sekä elintarvikkeiden tuottajat ja kuluttajat ovat alkaneet vaatia entistä tarkempaa tietoa tuotannossaan käyttämien raaka-aineiden ja kuluttamiensa lopputuotteiden alkuperästä. Siemenperunan tuotannossa lisääntynyt tiedontarve näkyy siemenperunayritysten asiakkaiden haluna saada aiempaa tarkempaa tietoa ruoka- ja teollisuusperunan viljelyssä käyttämästään sertifioidusta siemenperunasta ja sen laadusta.

Siemenperunan tuotantoketjusta kertyvän tiedon määrä on valtava. Entisestään lisääntyvää tietomäärää ei kyetä keräämään ja käsittelemään enää vanhoilla menetelmillä. Agro-, bio- ja informaatiotekniikoiden yhdistäminen tarjoaa uudenlaisen mahdollisuuden kerätä tätä tietoa ja hyödyntää sitä siemenperunaketjussa. Tekniikoiden ennakkoluuloton yhteiskäyttö yhdessä alan tutkimuksen kanssa luo pohjaa myös uusille innovaatioille. Tiedon keskitetty kerääminen, analysointi ja kohdennettu käyttö tarjoaa erinomaisen mahdollisuuden tehostaa suomalaisen siemenperunan tuotantoa ja vientiä. Kattava tiedonkeruu mahdollistaa myös entistä tarkemman jäljitettävyystiedon tarjoamisen sertifioitua siemenperunaa käyttäville perunanviljelijöille. Siemenperunan jäljitettävyysmalli ja sen pohjalta kehitetyn ePeruna-tuoteselostepalvelu antaa siemenperunayrityksen asiakkaalle tietoa sertifioidun siemenen viljelytoimenpiteistä sekä perunan ulkoisesta ja sisäisestä laadusta.

ePeruna on internetpalvelu, jonka tyyppistä ratkaisua ei ole tiettävästi toteutettu aikaisemmin maailmassa. Palvelu avaa siemenperunan kauppaerien yksityiskohtaiset laatutiedot asiakkaan käyttöön. Palvelusta saatava tuoteseloste sisältää mm. Elintarviketurvallisuusvirasto Eviran tekemien siemenperunan viljelys-, laboratorio- ja varastotarkastusten tulokset kustakin asiakkaan hankkimasta kauppaerästä. Palvelu on rakennettu siten, että asiakas saa käyttöönsä ainoastaan itselleen hankkimien siemenperunaerien tuoteselosteen.

Siemenperunan tuoteseloste on rakennettu osana Siemenperunasta Pohjoispohjanmaan vientituote -hanketta, jonka toteuttavat MTT (Maa- ja elintarviketalouden tutkimuskeskus) Ruukki ja Pohjoisen Kantaperuna Oy yhteistyössä kotimaisten ja kansainvälisten yhteistyökumppaneiden kanssa. Hanke on osa Pohjois-Pohjanmaan liiton hallinnoimaa eri toimialojen välisten innovaatioiden ja uusien palvelukonseptien syntyä tukevaa X-Branches ohjelmaa.

\section{Asiasanat}

peruna, siemenperuna, jäljitettävyys, tuoteseloste, tuoteturvallisuus, laatu, internet, sertifiointi, sertifioitu siemen, tarkastus 


\section{Johdanto}

Siemenperunatuotannolla on Pohjois-Pohjanmaan maakunnassa merkittävä rooli, sillä noin $80 \%$ valtakunnan sertifioidusta siemenperunasta tuotetaan alueella. Suurin osa tuotannosta markkinoidaan kotimaahan ja osa viedään Euroopan eri maihin. Siemenperunatuotannon keskittymiseen PohjoisPohjanmaalle on hyvät luontaiset edellytykset (kivettömät hietamaat, pitkän päivän tuotantoolosuhteet) sekä alueelle keskittynyt alan yritystoiminta.

Sertifioitua siemenperunatuotantoa voidaan lisätä huomattavasti nykyisestään. Suomen pohjoiset, vaarallisista taudeista ja tuholaisista puhtaat tuotanto-olosuhteet (High Grade -status) luovat erinomaiset edellytykset kilpailukykyiselle siemenperunatuotannolle. Siemenperunan liiketoiminnassa puhtaus kasvitaudeista on keskeinen kilpailuetutekijä. Siemenperuna-alan kehittämistoimet on keskitettävä siemenperuna-alan kilpailukyvyn ja viennin näkökulmasta oleellisimpiin asioihin. Siemenperunoiden on täytettävä tuotantotaustan ja laadun varmistuksen osalta tiukimmat mahdolliset vaatimukset ja ne on oltava todennettavissa. Nykyisin siemenperunatuotannon eri vaiheista syntyvä informaatio on hajanaista eikä sitä voida riittävästi hyödyntää. Tuotteen jäljitettävyyden ja laadun varmistaminen on kuitenkin keskeinen kilpailuetutekijä, johon on saatava uudenlainen informaation kokoamis-, seuranta- ja käsittelymalli.

MTT Ruukki ja Pohjoisen Kantaperuna Oy (Kantaperuna) käynnistivät toukokuussa 2006 yhteishankkeen, jonka yhtenä tavoitteena on kehittää suomalaisen siemenperunan tuoteselosteinternetpalvelu. Hankkeessa tehdään myös siemenperunan tuotantoon liittyvää biotekniikkatutkimusta, tutkitaan Pohjois-Pohjanmaan ilmasto-olosuhteiden vaikutusta siemenperunaan sekä kehitetään suomalaisen siemenperunan vientimahdollisuuksia. Hanke kuuluu Pohjois-Pohjanmaan liiton hallinnoimaan X-Branches ohjelmaan. Ohjelman tavoitteena on luoda uutta näkökulmaa innovaatiotoimintaan kehittämällä toimialojen ja alueiden välistä yhteistyötä.

\section{Aineisto ja menetelmät}

Rakennettu palvelu koostuu taustatietojärjestelmän tietokannasta, internetpalvelun relaatiotietokannasta ja web-sovelluksesta. Taustajärjestelmän tietokantaan kerätään kaikki siemenperunan viljelyn aikana kertyvä viljelytapahtuma-, sääasema-, analyysi- ja tarkastustieto sekä jäljitettävyysketjun rakentamisessa tarvittavat asiakastiedot. Tästä tiedoista poimitaan tietokantahakujen avulla tuoteselosteessa esitettävät tiedot ja nämä siirretään internetpalvelun tietokantaan. Palvelun asiakaskäyttöä ja ylläpitoa varten on toteutettu erilliset web-käyttöliittymät.

Järjestelmään kerättävä tieto saadaan tiedontoimittajilta xml-, csv- ja xls-tiedostomuodoissa sekä paperidokumentteina. Tiedostot konvertoidaan ja viedään tietokantaan. Paperidokumenteista poimittavat tiedot kirjataan tietokantaan ylläpitokäyttöliittymän kautta.

\section{Tiedon keruu viljelijöiltä}

Kantaperunan viljelijät käyttävät ProAgrian Wisu-viljelysuunnitteluohjelmistoa omalla tietokoneellaan. Wisu-ohjelma sisältää peruslohkokirjanpidon, viljelysuunnitteluominaisuudet, välineet kasvintuotannon talouden suunnitteluun ja seurantaan, karttakäyttöliittymän sekä sähköiset asiointimahdollisuudet. Viljelijät tallettavat Wisuun peltojen kasvulohkojen viljavuustiedot, lohkojen muokkaustapahtumat, perunan istutukseen ja siemen laatuun liittyvät tiedot, lannoitustapahtumat ja käytetyt lannoitteet, käytetyt kasvinsuojeluaineet ja niiden käyttömäärät, kasvitautihavainnot sekä sadon määrän. Wisuun kerätty tieto lähetetään ProAgrian Lohkotietopankki-tietokantaan, josta data siirretään ePerunapalvelun taustajärjestelmään.

\section{Sertifiointitarkastusten tiedot}

Elintarviketurvallisuusvirasto Evira suorittaa Suomessa viljellyn siemenperunan sertifiointiin liittyvät viljelys-, laboratorio- ja varastotarkastukset kullekin asiakkaalle toimitettavalle siemenperunan kauppaerälle. Viljelystarkastuksen tulokset kertovat siementuotantolohkon kasvukauden aikaisesta kasvitautitilasta. Laboratoriotarkastuksessa tutkitaan kasvitautien esiintymistä siemenperunaerän mukuloissa. Varastotarkastus tehdään siemenerälle lajittelun yhteydessä, juuri ennen sen toimittamista asiakkaalle. Tarkastuksessa tutkitaan mm. erän ulkoinen laatu ja mahdolliset bakteeritautiesiintymiset. Siemenperunaerän laatuluokka määräytyy tehtyjen tarkastusten perusteella. Jokaiselle tarkastuksissa tutkittavalle seikalle on asetettu tarkat laatuluokkakohtaiset raja-arvot. Eviran tekemien tarkastusten tie- 
toja saadaan sekä tiedostoina että paperidokumentteina. Papereista tieto syötetään käsin palvelun tietokantaan.

Siemenperunaa tuodaan Suomeen myös muista EU-maista. Nämä siemenerät on virallisesti tarkastettu ja sertifioitu jo lähtömaassa. Tämän lisäksi Evira tekee tuodulle siemenperunalle maahantuontitarkastuksen.

\section{Sääasemadata}

Kantaperunalla on käytössään useita a-Lab Oy:n valmistamaan a-Weather -sääasemia. Asema lähettää mittaustiedot GSM-verkon avulla internetissä sijaitsevaan a-Log.net-mittaustietoportaaliin ja tietokantaan. Tästä tietokannasta Kantaperunan sääasemien tiedot haetaan internetpalveluun. Taustajärjestelmään talletetaan ilman lämpötilan, kasvukauden aikainen lämpösumma ja sademäärä, maan lämpötila sekä maan kosteus.

\section{Muu kerättävä tieto}

Kantaperuna on käytössään laadunhallintajärjestelmä, jonka avulla yhtiö varmistaa toimittamiensa tuotteiden ja palveluiden täyttävän määritellyt vaatimukset. Osana laadunvarmistustaan yritys tekee kaikille tuottamilleen siemenperunaerille laatuanalyysin. Analyysin tarkoituksena on saada mahdollisimman tarkka arvio tuotetun siemenperunan määrästä ja laadusta jo ennen virallisia sertifiointipäätöksiä. Laatuanalyysissä arvioidaan siemenperunan ulkoista ja sisäistä laatua.

Omien laatuanalyysien lisäksi Kantaperuna käyttää MTT Ruukin perunalaboratorion tarjoamia analyysipalveluja. Laboratoriossa analysoidaan $\mathrm{mm}$. piilevää tyvimätää ja perunan virustauteja. Teetettyjen analyysien tulokset talletetaan palvelun tietokantaan.

Jotta perunaerä saadaan yhdistettyä asiakkaaseen ja tälle voidaan antaa pääsy kyseisen erän tuoteselosteeseen, tarvitaan palvelun käyttöön yrityksen laskutustietoja. Laskutustiedoista palvelun tietokantaan talletetaan vain ne tiedot joiden avulla asiakkaan ja kauppaerän yhdistäminen voidaan tehdä.

Ulkomailta tuodulla siemenperunalla on takanaan pitkä viljelyhistoria erän saapuessa Suomeen. Lajikejalostajan toimittamat kauppaerän tiedot talletetaan niin ikään palveluun, jotta perunan jäljitettävyysketjusta saadaan aukoton.

\section{Tuoteselosteen sisältö ja palvelun käyttö - ePeruna}

Palvelun määritysvaiheessa Kantaperunan asiakkaiden keskuudessa suoritettiin kysely, jolla selvitettiin siemenperunan jäljitettävyyden ja laatutiedon merkitystä ruokaperunanviljelijöille. Tuoteselosteen tietosisältö koottiin kyselyn tulosten perusteella. Tuoteseloste sisältää tiedot perunaerän viljelijästä, viljelypaikkakunnasta, perunalajikkeesta, erän siemenluokasta, kokoluokasta (vaihteluväli millimetreinä) ja perunaerän keskimääräisen mukulapainon grammoina, tiedon erän viljelyn aikana käytetyistä kasvinsuojeluaineista sekä Eviran tekemien tarkastusten tulokset. (Kuva 1).

Siemenperunan ostajat saavat tuoteselosteen käyttöönsä ePeruna-internetpalvelusta. Tuoteselosteen sisältö koostuu siemenperunan viljelyn ja varastoinnin eri vaiheista kerättävästä informaatiosta sekä virallisten sertifiointitarkastusten tuloksista. Tuoteselosteen avulla voidaan todentaa siemenperunan tuotantotausta ja varmistaa sen laatu. Siemenperunan tuotantotiloilta ja useista muista informaatiolähteistä tulevat tiedot tallennetaan tietokantapohjaiseen järjestelmään. Tietokantaan kerättävä tieto on edelleen käytettävissä tuoteselosteessa sekä siemenperunatuotannon laadun kehittämisessä.

Tuoteselosteesta on pyritty tekemään mahdollisimman helppokäyttöinen. Palvelun asiakaskäyttäjä kirjautuu palveluun henkilökohtaisilla tunnuksillaan ja saa näkyviin listan hankkimistaan siemenperunan kauppaeristä. Kauppaerän numero toimii linkkinä tuoteselosteeseen. Käyttäjä voi halutessaan tulostaa tuoteselosteen. Palvelun yksinkertaisella rakenteella on pyritty madaltamaan sähköisten palvelujen käyttöönottokynnystä.

Palvelun rakentamisessa on huomioitu tuoteselosteessa esitettävien tietojen luottamuksellisuus ja tietoturvallisuus. Palvelun käyttöoikeudet on määritelty siten, että kukin palvelun käyttäjä näkee vain hankkimiensa siemenperunaerien tiedot.

\section{Kerätyn tiedon hyödyntäminen tutkimuksessa}

Vain pieni osa kerätystä siemenperunan jäljitettävyystiedosta esitetään tuoteselosteessa. Valtaosa tiedosta on sellaista, ettei sillä ole välitöntä hyötyä siemenperunaa käyttävälle ruokaperunanviljelijälle. 
Tätä tietoa voidaan kuitenkin hyödyntää siemenperunaan liittyvässä tutkimuksessa ja siemenperunatuotannon kehittämisessä. Koska tietokantaan on tallennettu kattavasti tieto siemenperunan tuotantotausta ja laadusta, voidaan tätä dataa analysoimalla pyrkiä löytämään perunan laatuun ja tuotannon onnistumiseen vaikuttavia syy-seuraussuhteita.

Kootun tiedon lajikekohtainen analysointi tuo lisätietoa lajikkeen kasvukäyttäytymisestä ja auttaa tarkentamaan sen tuotanto-ohjeistusta. Kasvitautien tuotanto-olosuhde- ja tuotantotaustariippuvuuksista saatava lisätieto mahdollistaa vaikuttamisen taudintorjuntaan ja -kestävyyteen. Tutkimuksen tavoitteena on siemenperunan laadun ja tuotannon kehittäminen sekä sitä kautta kannattavuuden parantaminen.

\section{Kantaperuna}

NORTHERN SEED POTATO

Leppiojantie 11

91800 Tyrnävä

Puh. 0207614800

Fax (08) 5617820

Alv rek. 0678812-6

\begin{tabular}{|l|l|}
\hline Kauppaerän numero & $1346-6401601 / 1$ \\
\hline Viljelijä & Kantola Markku \\
\hline Paikkakunta & Tyrnävä \\
\hline Perunalajike & Victoria \\
\hline Erän siemenluokka & A \\
\hline Mukulapaino $(g)$ & 39 \\
\hline Kokoluokka $(\mathrm{mm})$ & $30-40$ \\
\hline
\end{tabular}

Kasvinsuojelutapahtumat

\begin{tabular}{|l|l|}
\hline Aine & Käyttökerrat \\
\hline \hline Maxim 100 FS & 1 \\
\hline \hline Senkor & 1 \\
\hline \hline Agil 100 EC & 1 \\
\hline Ranman Twinpack & 1 \\
\hline Shirlan & 4 \\
\hline Karate 2.5 WG & 2 \\
\hline \hline Reglone & 1 \\
\hline
\end{tabular}

Viljelystarkastus

\begin{tabular}{|l|c|}
\hline Päivämäärä & 10.8 .2006 \\
\hline Vieraat lajikkeet $(\%)$ & 0 \\
\hline Tyvimàtä $(\%)$ & 0 \\
\hline Ankaraa vir oosia $(\%)$ & 0 \\
\hline Viroottisia yht. $(\%)$ & 0 \\
\hline Perunaseittiä $(\%)$ & 0 \\
\hline Poistettuja yksilötä $(\%)$ & 0 \\
\hline
\end{tabular}

Eviran vilielivstarkastuksen laatuvaatimukset

www.kantaperuna.com
Laboratoriotarkastukset

\begin{tabular}{|l|l|}
\hline Rengasmäta $(\%)$ & 0 \\
\hline A-virus $(\%)$ & 0 \\
\hline M-virus $(\%)$ & 0 \\
\hline PLRV-virus $(\%)$ & 0 \\
\hline S-virus $(\%)$ & 0 \\
\hline X-virus $(\%)$ & 0 \\
\hline Y-virus $(\%)$ & 1 \\
\hline
\end{tabular}

Eviran laboratoriotarkastuksen lagtuvaatimukset

Varastotarkastus

\begin{tabular}{|l|c|}
\hline $\begin{array}{l}\text { Mop-top ja rattle - } \\
\text { virusta (\%) }\end{array}$ & 0 \\
\hline Perunarupea (\%) & 0 \\
\hline $\begin{array}{l}\text { Seitti-, känsä-tai } \\
\text { syvärupea }(\%)\end{array}$ & 2,15 \\
\hline $\begin{array}{l}\text { Mekaanista tai } \\
\text { fysiologista vioitusta }(\%)\end{array}$ & 0,13 \\
\hline Alimittaisia mukuloita $(\%)$ & 0,64 \\
\hline Ylimittaisia mukuloita $(\%)$ & $<1$ \\
\hline Multaa ja roskia $(\%)$ & \\
\hline
\end{tabular}

Eviran varastotarkastuksen fagtuvaatimukset

Kuva 1. Esimerkki tuoteselosteesta. 